\title{
The Impact of Alcohol Consumption on Excess Male Mortality in Nineteenth- and Early Twentieth-Century Sweden
}

\author{
Sam Willner
}

\section{Introduction}

weden has the lowest per capita consumption of alcohol in Western Europe S together with the Nordic sister nations Norway and Iceland, according to recent official statistics. ${ }^{1}$ Alcohol-related deaths are consequently low in a European perspective. ${ }^{2}$ This level is ascribed to the Swedish policy based on farreaching administrative restrictions and on the high taxes imposed on alcohol sale. However, ideological influences that encourage conscientiousness and temperance have also been exercised historically by strong popular movements: the absolutist temperance societies, working class organisations and the non-conformist free churches (outside the Swedish Lutheran Church). Many of those who defend this system with a low consumption policy today foresee great risks regarding the social and health-related consequences if the European Union efforts to liberalise the restrictive Swedish policy in order to 'harmonise' trade in alcoholic beverages are carried through. ${ }^{3}$ The great interest in alcohol in the contemporary debate on public health issues in Sweden motivates a closer examination of the historical experiences with alcohol policies and traditions regarding consumption levels and health effects.

1 Folkhälsoinstitutet/Centralförbundet för alkohol och narkotikaupplysning, Drogutvecklingen i Sverige, Rapport 2000 (Stockholm, 2000), table 60. In this report sales data are used as proxies for ranking consumption levels.

2 See, for example, national rates of diagnosis chronic liver disease and cirrhosis (ICD 9: 571) in UN Demographic Yearbook.

3 See, for example, Svenska alkoholvanor i förändring. Om utvecklingen fram till EUmedlemskapet, eds. E. Kühlhorn and J. Björ (Stockholm, 1998). 


\section{Previous Findings}

Some years ago, Gunnar Fridlizius suggested that excessive drinking of liquor largely contributed to the marked male 'mortality hump' among adults in early nineteenth century. ${ }^{4}$ Alcohol consumption was also a common explanation of excess male death rates among late nineteenth century observers, and this hypothesis has even been proposed by more recent scholars. ${ }^{5}$

In a lecture for the Swedish Medical Society in 1879 the Swedish physician Gerhard Westfelt claimed that excessive drinking played an important role in the unfavourable death rates of urban men. The simultaneous peaks of alcohol consumption and excess male mortality around the middle of the 1870s supported this view. ${ }^{6}$

In Denmark alcohol consumption was radically reduced from about ten litres per capita (ages 15+) in the years preceding the First World War to two litres in 1918, a reduction primarily caused by considerable increases in the prices of alcoholic beverages and legal restrictions motivated by the wartime crisis. The consumption level then stabilised on a level of three to four litres per capita and year during the following decades with a permanent policy of high alcohol prices. The simultaneous fall in excess male mortality in Danish towns was attributed to the declining alcohol consumption.

On the basis of the evidence from graphical presentations of historical data series from some European countries, Sully Ledermann has claimed that the per capita consumption of alcohol had a clear effect on excess male mortality levels. ${ }^{8}$ The Swedish sociologist Thor Norström made a more sophisticated analysis of this type of data, using modern time-series analysis (Box and Jenkins technique). The results

4 G. Fridlizius, 'Sex-Differential Mortality and Socio Economic Change. Sweden 17501910', in Society, Health and Population during the DemographicTransition, eds. A. Brändström and L-G. Tedebrand (Stockholm, 1988).

5 S. Ledermann, Alcool, Alcoolisme, Alcoolisation. Vol. 2. Mortalité, morbidité, accidents du travail (Paris, 1964); T. Norström, 'Per capita alcohol consumption and total mortality: an analysis of historical data', Addiction, 91:3 (1996), 339-344.

6 G. Westfelt, 'Om dryckenskapens tillstånd och fysiska följder i Sverige under åren 1861-77 enligt statistikens vittnesbörd. Föredrag vid nedläggandet af Ordförandeskapet i Svenska Läkare-Sällskapet d. 7 oktober 1879', Svenska Läkare-Sällskapet Nya Handlingar, Ser. II, del VII. 2 (Stockholm, 1880).

7 M. Hindhede, 'Nogle Sider af Alkoholsporgsmaalet', in Betaenkning afgiven af den af indenrigesministeriet under 16. Juki 1914 nedsatte 2. Aedruelighedskommission, II afsnit (Copenhagen, 1927); T.Thorsen, Hundrede Ars Alkoholmisbrug. Alkoholforbrug og alkoholproblemer i Danmark (Copenhagen, 1990).

8 This data was originally analysed by Rudolf Bandel in studies around 1930. S. Ledermann, Alcool, Alcoolisme, Alcoolisation. Vol. 2. Mortalité, morbidité, accidents du travail (Paris, 1964). 
suggest that an increase of consumption by one litre per capita among adults entails an increase in male mortality by around one per cent.' Similar results have been reported from a time-series analysis of Swedish data for the period 1861-1913..$^{10}$

Time-series analyses for the post-war period in Sweden suggest that variations in alcohol consumption had a relatively strong impact on subsequent changes in excess male mortality. ${ }^{11}$ According to official Swedish statistics, about 30 per cent of the total excess male mortality in the early 1990s could be attributed to some alcohol-related diagnoses (underlying or contributing causes) as identified by the International Classification of Diseases (ICD). ${ }^{12}$

Alcohol consumption is certainly not the only factor affecting the sex differences in mortality in present time and in the past. There are also genetic/biological factors as well as gender related differences in behaviour and occupational roles. ${ }^{13}$ Factors such as a labour market that discriminated against men in pre-industrial towns, ${ }^{14}$ increased exposure to infectious diseases (smallpox) for men because of greater mobility, ${ }^{15}$ health risks connected to typical male work and a less orderly life-style ${ }^{16}$ have been suggested as causes of the excess male death rates in nineteenth-century. The sex differences were of course also affected by factors disadvantageous to the health of women, for example, potential nutritional discrimination, ${ }^{17}$ risks of expo-

9 Per capita consumption of alcohol and excess male mortality (ages 40-49) in Prussia, 1887-1918, and male mortality (ages 35-59) in France, 1885-1958. T. Norström, 'Per capita alcohol consumption and total mortality: an analysis of historical data', Addiction, 91:3 (1996), 339-344.

10 T. Norström, 'Real wages, alcohol consumption and mortality in Sweden, 1861-1913', European Journal of Population, 4 (1988), 183-196.

11 Ö. Hemström, 'Explaining Differential Rates of Mortality Decline for Swedish Men and Women: A Time-Series Analysis, 1945-1992', Social Science and Medicine, 48:12 (1999), $1759-1777$.

12 ICD 9: 291, 303, 305.0, 357.5, 425.3, 571.0-571.3, E860 and E980+980. Dödsorsaker 1991-95, Statistiska Centralbyrån (SCB).

13 I. Waldron, 'What do we know about causes of sex differences in mortality? A review of the literature', Population Bulletin of the United Nations, 18 (1985); L. Verbrugge, 'Gender and Health: An Update on Hypotheses and Evidence', Journal of Health and Social Behaviour, 26 (1985); S. R. Johansson, 'Welfare, Mortality and Gender. Continuity and Change in Explanations for Male/Female Mortality over Three Centuries', Continuity and Change, 6:2 (1991), 135-177.

14 J. Söderberg et al., A Stagnating Metropolis: The Economy and Demography of Stockholm, 1750-1850 (Cambridge, 1991).

15 P. Sköld, The Two Faces of Smallpox. A Disease and its Prevention in Eighteenth-and Nineteenth-Century Sweden (Umeå, 1996).

16 J. A. Leyonmarck, 'Angående Svenska Tabellverket, och om Folkmängden m. m. i Riket under de ifrån 1815 sistförflutne 25 åren', Kungl. Vetenskapsakademiens Handlingar (1845).

17 S. R. Johansson, 'Deferred Infanticide: Excess Female Mortality during Childhood', in Infanticide: Comparative and Evolutionary Perspectives, G. Hausfater and S. B. Hrdy, (New York, 1984); S. Nicholas and D. Oxley, 'The Living Standards of Women during the Industrial 
sure to tuberculosis in household work, ${ }^{18}$ and hazards connected to pregnancies and deliveries. ${ }^{19}$ However, the evidence supporting the idea of alcohol consumption being an important factor in the development of excess male mortality in nineteenth-century Sweden motivates further analyses of this question.

\section{The Purpose}

This article discusses the importance of alcohol for gender differences in mortality, particularly among middle-aged adults, on the basis of Swedish evidence during the pre-industrial or transitional period, c.1800-1860, and the industrial breakthrough, c. $1860-1930 .^{20}$ Administrative measures, socio-economic and cultural factors affecting drinking habits and the consumption levels of alcoholic beverages will be tentatively discussed. Compared to previous studies a more systematic approach is used to further test the common hypothesis of an alcohol boom during the first half of the nineteenth-century. A preliminary discussion is introduced on the impact of drinking habits on mortality differences among certain categories of males, classified on the basis of marital status, social class and urban-rural residence.

\section{Sex Differential Mortality in Sweden 1751-1930}

During the old demographic regime crude death rates fluctuated strongly. Sharp rises in mortality often occurred in times of war and crop failures, as was the case $1772-73,1789$ and around 1809 . The two latter tops were largely a product of epidemics connected to wartime conditions, which particularly struck men in military service, resulting in the marked peaks we can observe for the sex ratio of mortality among younger adults (Figure 1). From about 1810 onward a permanent reduction

Revolution 1795-1820', Economic History Review, XLVI:4 (1993), 723-749; S. Klasen, 'Marriage, Bargaining, and Intrahousehold Resource Allocation: Excess Female Mortality among Adults during Early German Development, 1740-1860', Journal of Economic History, 58:2 (1998), 423467.

18 G. Fridlizius, 'Sex-Differential Mortality and Socio Economic Change, Sweden 17501810', in Society, Health and Population during the Demographic Transition, eds. A. Brändström and L-G. Tedebrand (Stockholm, 1988).

19 U. Högberg, Maternal Mortality in Sweden (Umeå, 1985). For a general discussion on gender differences in mortality in nineteenth-century Sweden, see S. Willner, Det svaga könet? Kön och vuxendödlighet $i$ 1800-talets Sverige (Linköping, 1999).

20 The analysis of the nineteenth-century is primarily based on my dissertation: S. Willner, Det svaga könet? Kön och vuxendödlighet i 1800-talets Sverige (Linköping, 1999), while some new results are presented for the early twentieth-century. 
of death rates is evident among children, youths and women in active ages, while adult males exhibit relatively unchanged or even increasing levels, which led to marked excess male mortality in the ages 25-60 during the first half of the century. The contemporary explanation of 'peace, vaccine and potatoes' captures some important factors leading to decreasing crude death rates, but cannot explain why this was not the case among adult men. A dramatic growth of property-less people, largely resulting from downward social mobility among the rural population characterised the period..$^{21}$ In spite of the rapid growth of the rural proletarians, there are indications of improvements in the general nutritional standard during the period. The impact on mortality from harvest fluctuations decreased compared to the previous century, and the trend in heights was clearly upward. ${ }^{22}$ The 'hump' in excess male mortality in the 1820 s to 1840 s was most accentuated in ages $25-60$, and has been attributed to the great increase in brännvin (Swedish liquor distilled from grain or potatoes) consumption during this period.

During the last decades of the nineteenth and the early twentieth centuries a rapidly decreasing trend in the sex ratio in mortality is observable, but it was temporarily broken around the turn of the century. In younger ages the peak around 1918-19 was a product of the Great Influenza Epidemic, which had a larger impact on male mortality levels. In the age group 40-59 years a sharp fall in the ratio occurs after 1915. The period of industrial breakthrough was also characterised by a general decline in adult mortality, particularly in urban areas. Public health measures, such as the construction of effective systems for water supply and sewage, contributed to significant improvements in sanitary conditions in the growing towns, and they were accompanied by diminishing excess mortality in urban areas compared to the countryside. In the initial phase of industrialisation some peaks in mortality, however, can be attributed to the effects of overcrowding and poor housing conditions. These developments were associated with intensified movement to cities and industrial centres in times of industrial booms and improved opportunities on the labour market, the clearest example of which can be found during the prosperous years of mid-1870s. Males were more affected than females, probably because a majority of those urban immigrants were men. ${ }^{23}$

21 C. Winberg, Folkökning och proletarisering (Göteborg, 1975).

22 T. Bengtsson and R. Ohlsson, Levnadsstandard och mortalitet i Sverige 1750-1860 (Lund, 1984); L. G. Sandberg and R. H. Steckel, 'Was Industrialization Hazardous to Your Health? Not in Sweden!', in Health and Welfare during Industrialization, eds. R. H. Steckel and R. Floud (Chicago, 1997).

23 D. S. Thomas, Social and Economic Aspects of Swedish Population Movements, 1750 1933 (New York, 1941), 107. 
Figure 1. Sex ratio of mortality rates in ages 15-79 (females=100). Sweden 17511930. Five year averages.

a) $15-24 / 24-44$ years.

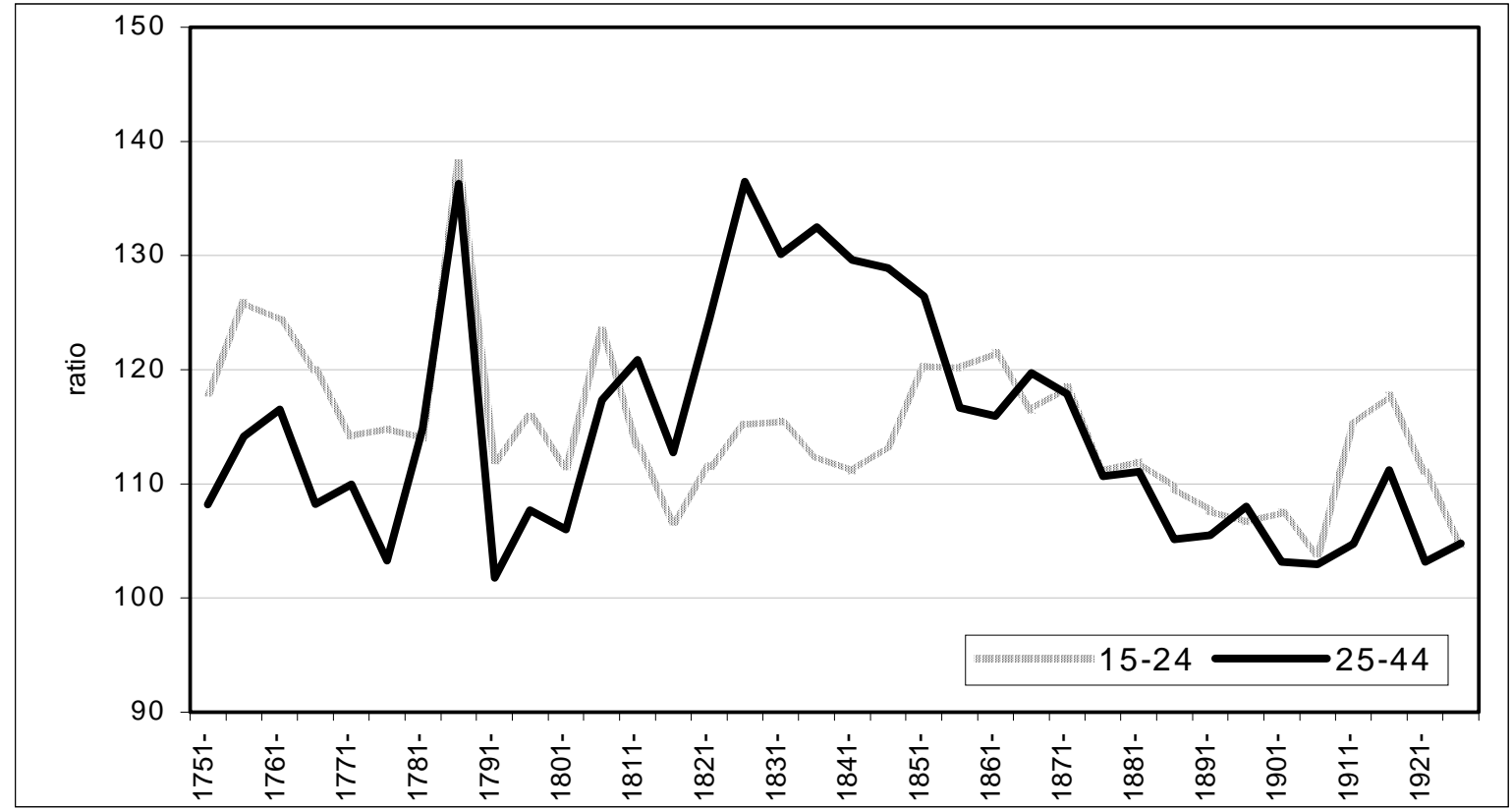

b) 45-59/60-79 years.

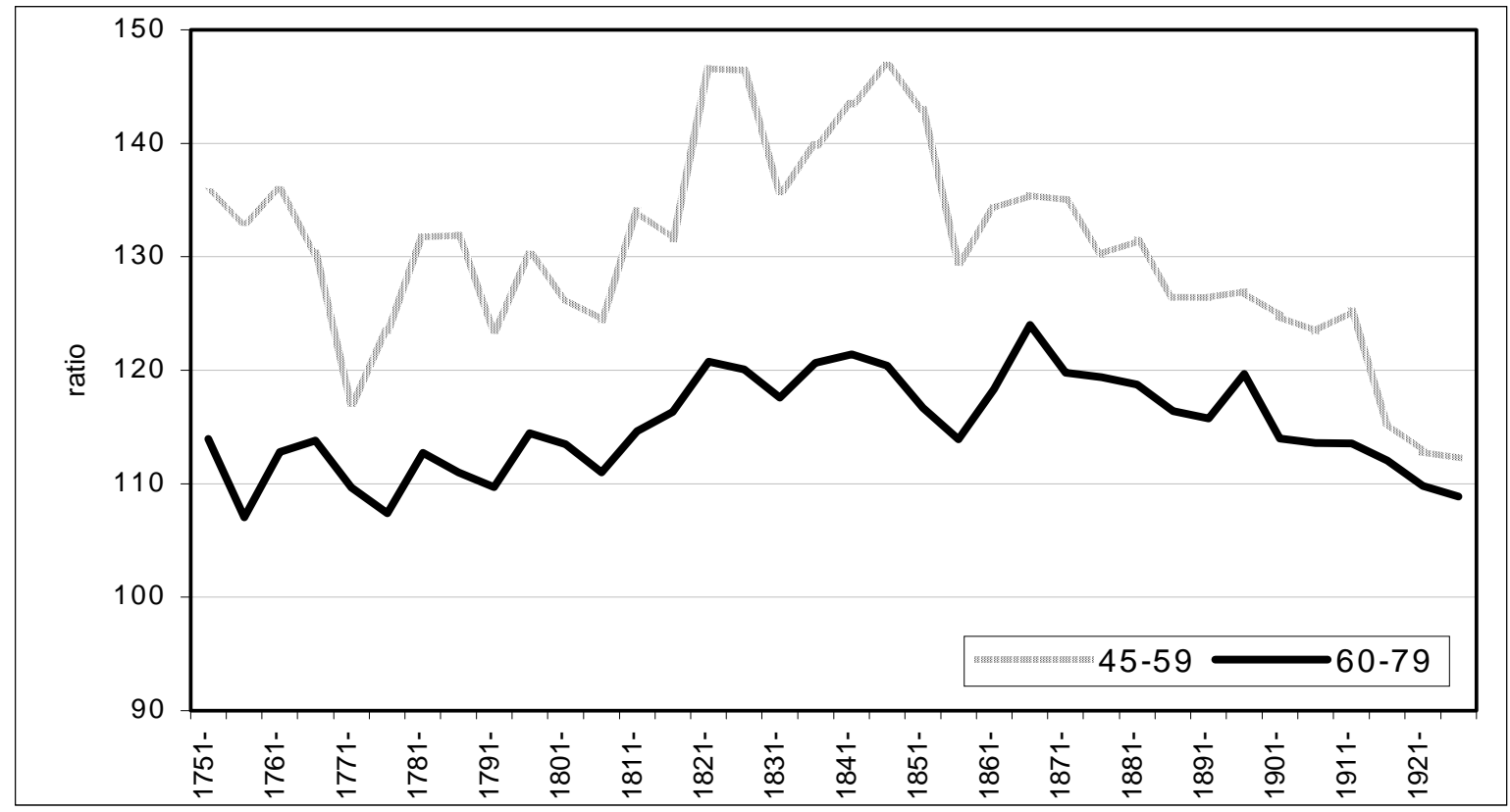

Sources: G. Sundbärg, 'Fortsatta bidrag till en svensk befolkningsstatistik för åren 1750-1900', Statistisk Tidskrift (1909); Statistics Sweden. 


\section{Alcohol Consumption and Mortality in Transitional Sweden, c. $1800-1860$}

\section{Alcohol consumption}

Gunnar Fridlizius has named several factors as facilitating the production and sale of liquor in the early nineteenth-century: very liberal legislation on household distilling, introduced in 1810; the introduction of potatoes as raw material in liquor production; and the possibility of large scale production in the new steam distilleries. ${ }^{24}$

Public opinion regarding the use of alcohol was also an important factor. Although physicians of the time claimed that excessive drinking could be devastating for one's health, the attitudes to alcohol found in broader social groups were in general positive and it was described as

the only pleasure the Swedish peasant can prepare at home for his refreshment during hard work, for encouragement of his servants, to the delight of his guests and for the preparation of his medicine. ${ }^{25}$

This passage from the minutes of the Estate of the Peasantry recorded during the parliamentary sessions of 1778-79 probably expressed a widespread opinion of the time. Brännvin was used in the daily diet as well as for festivities. It was considered to be important for enduring heavy work, and it was a common part of the wages paid servants and other employees. Alcohol was also an essential ingredient in folk medicine. ${ }^{26}$

The cultural acceptance of drinking was much more restricted for women than men, and, according to the literature of the day, heavy drinking was a predominantly male phenomenon. ${ }^{27}$ Contemporary statistics on alcohol-related deaths and on arrests for the offence of drunkenness strongly support this view. ${ }^{28}$ For example, the proportion of females among the registered cases of deaths attributed to alcohol

24 See also, T. Larsson, Reformen i brännvinslagstiftningen 1853-1854. Förhistorien (Stockholm, 1945).

25 Bondeståndets riksdagsprotokoll 1778-1779, ed. Sten Landahl (Stockholm, 1986).

26 See E. Rasch, 'Brännvinsbruket i 1800-talets skånska bondesamhälle', Skånes hembygdsförbunds årsbok (1974); M. Hellspong and O. Löfgren, Land och stad (Malmö, 1994), 168; M. Huss, Om Sveriges endemiska sjukdomar (Stockholm, 1852), 126; C. H. Tillhagen, Folklig läkekonst (Stockholm, 1962).

27 For example, M. Huss, Alcoholismus Chronicus eller Chronisk Alkoholsjukdom II (Stockholm, 1851), 171.

28 S. Willner, Det svaga könet? Kön och vuxendödlighet i 1800-talets Sverige (Linköping, 1999), 168. 
intoxication did not exceed 12 per cent for any five-year period during the first half of the nineteenth-century. ${ }^{29}$

The great socio-economic and cultural transformations of the time, which gave uncertain prospects for the future among the rapidly growing proletarian groups reduced hope for employment and building a family - probably contributed to a climate which stimulated excessive alcohol consumption, as did a weakening of informal social control..$^{30}$ As heavy drinking was a predominantly male behaviour, it is likely that the negative health effects would be particularly accentuated among men. This has also been observed in the transitional societies of Russia and other eastern European countries during recent decades. Heavy alcohol consumption has been suggested as a major factor in the dramatic decline in life expectancy, particularly for males, in post-communist Russia. ${ }^{31}$

According to several studies, social drinking at taverns was a fundamental part in the culture of certain groups of craftsmen and workers and for maintaining important social networks in pre-industrial towns. ${ }^{32}$ This probably also contributed to excessive drinking.

A growing discussion about the social question and a concern for socio-economic or moral problems connected to excessive drinking among the proletarians gradually gained ground in the propertied classes, including land-owning peasants, during the first half of the century. ${ }^{33}$ There are even examples of violent actions against the distilleries among working class groups in the mid-nineteenth-century, because the large scale production of brännvin strongly contributed to increasing prices for

29 G. Westfelt, 'Om dryckenskapens tillstånd och fysiska följder i Sverige under åren 1861-77 enligt statistikens vittnesbörd. Föredrag vid nedläggandet af Ordförandeskapet i Svenska Läkare-Sällskapet d. 7 oktober 1879', Svenska Läkare-Sällskapet Nya Handlingar, Ser. II, del VII. 2 (Stockholm, 1880), 43.

30 For a short description on the agrarian-to-industrial transitional period in Sweden, see J. Sundin, 'Worlds we have lost and worlds we may regain. Two centuries of changes in the life course in Sweden', The History of the Family, 4:1 (1999), 93-112.

31 For example, P. Carlsson and D. Vågerö, 'The social pattern of heavy drinking in Russia during transition: Evidence from Taganrog 1993', European Journal of Public Health, 8 (1998), 280-285; P. Walberg et al., 'Economic change, crime, and mortality crisis in Russia: regional analysis', British Medical Journal, 317 (1998), 312-318; W. C. Cockerham, Health and Social Change in Russia and Eastern Europe (New York, 1999). It has, however, been argued that the evidence so far presented is not sufficient for accepting the alcohol hypothesis. See, for example, M. Bobak and M. Marmot, 'Alcohol and mortality in Russia: is it different than elsewhere?', Annals of Epidemiology, 9:6 (1999), 339-340.

32 For example, L. Magnusson, Den bråkiga kulturen. Förläggare och Smideshantverkare i Eskilstuna 1800-1850 (Stockholm, 1988).

33 See B. Petersson, 'Den farliga underklassen.' Studier i fattigdom och brottslighet i 1800talets Sverige (Umeå, 1983); J. Sundin, 'Control, punishment and reconciliation. A case study of parish justice in Sweden before 1850', in Tradition and Transition. Studies in micro-demography and social change, eds. A. Brändström and J. Sundin (Umeå, 1981). 
grain and potatoes. ${ }^{34}$ The pioneering work by Magnus Huss, Alcoholismus Chronicus, published around 1850, gave weight to medical concerns about excessive drinking. In the light of this, the more restrictive legislation in mid-nineteenth-century is logical. But there were also underlying economic motives regarding the control of profits from the production and trade of liquor. ${ }^{35}$

Contemporary estimates of the Swedish consumption (or production) of liquor during the period from about 1820-1850 roughly amount to about 10-15 litres (100\% alcohol) per capita annually, while corresponding figures for the late eighteenth and early nineteenth-century were approximately five litres or less (based on total population). The latter is roughly the same level that was registered in the official statistics of the latter part of the nineteenth-century. ${ }^{36}$ The estimations preceding the introduction of official alcohol statistics, usually based on calculations of production capacity or the quantity of grain used for distilling liquor, are certainly very unreliable. The great differences in estimated levels between different periods, however, suggest that consumption culminated between the 1820s and 1840s or early 1850 s.

According to the Swedish physician Magnus Huss, a 'moderate' consumer of liquor, representing male workers of Stockholm in mid-nineteenth-century, drank about 40-45 centilitres of brännvin (c. 45\% alcohol) each working day and often the double amount on Sundays, that is at least 150 litres per year. Roughly the same levels of consumption were noted by contemporary observers for other groups of male workers, for example, miners in Norberg in the province of Västmanland and adult males in Eskilstuna, a town dominated by iron working and production of metal tools and implements. ${ }^{37}$ Similar levels, about one-half litre of brännvin daily, were reported for heavy drinkers among male workers in Stockholm around the turn of the century $1900,{ }^{38}$ indicating a general decrease in consumption during the last half of the nineteenth-century.

The reports of the county governors agreed that the alcohol legislation of 1855 caused a considerable and secular decline in alcohol consumption all over the country, at least in rural areas. ${ }^{39}$ In addition, the growth of recorded offences of

34 R. Karlbom, Hungerupplopp och strejker 1793-1867. En studie i den svenska arbetarrörelsens uppkomst (Lund, 1967), 112.

35 P. Frånberg, 'Den svenska supen', in Den svenska supen. En historia om brännvin, Bratt och byråkrati, eds. K. Bruun and P. Frånberg (Stockholm, 1985).

36 S. Willner, Det svaga könet? Kön och vuxendödlighet i 1800-talets Sverige (Linköping, 1999), 178.

37 M. Huss, Om Sveriges endemiska sjukdomar (Stockholm, 1852), 93; L. Magnusson, Den bråkiga kulturen. Förläggare och Smideshantverkare i Eskilstuna 1800-1850 (Stockholm, 1988), 45 (quoting hospital doctor P. C. Malm of Eskilstuna, 1851).

38 C. T. Scholander, 'Några iakttagelser angående alkoholismen bland arbetsklassen i Stockholm', Hygiea (1903:II).

39 S. Willner, Det svaga könet? Kön och vuxendödlighet i 1800-talets Sverige (Linköping, 
Figure 2. Indices of alcohol-related deaths and autopsies, domestic distribution of liquor, and homicides per capita. 1800-1870. (1853=100).

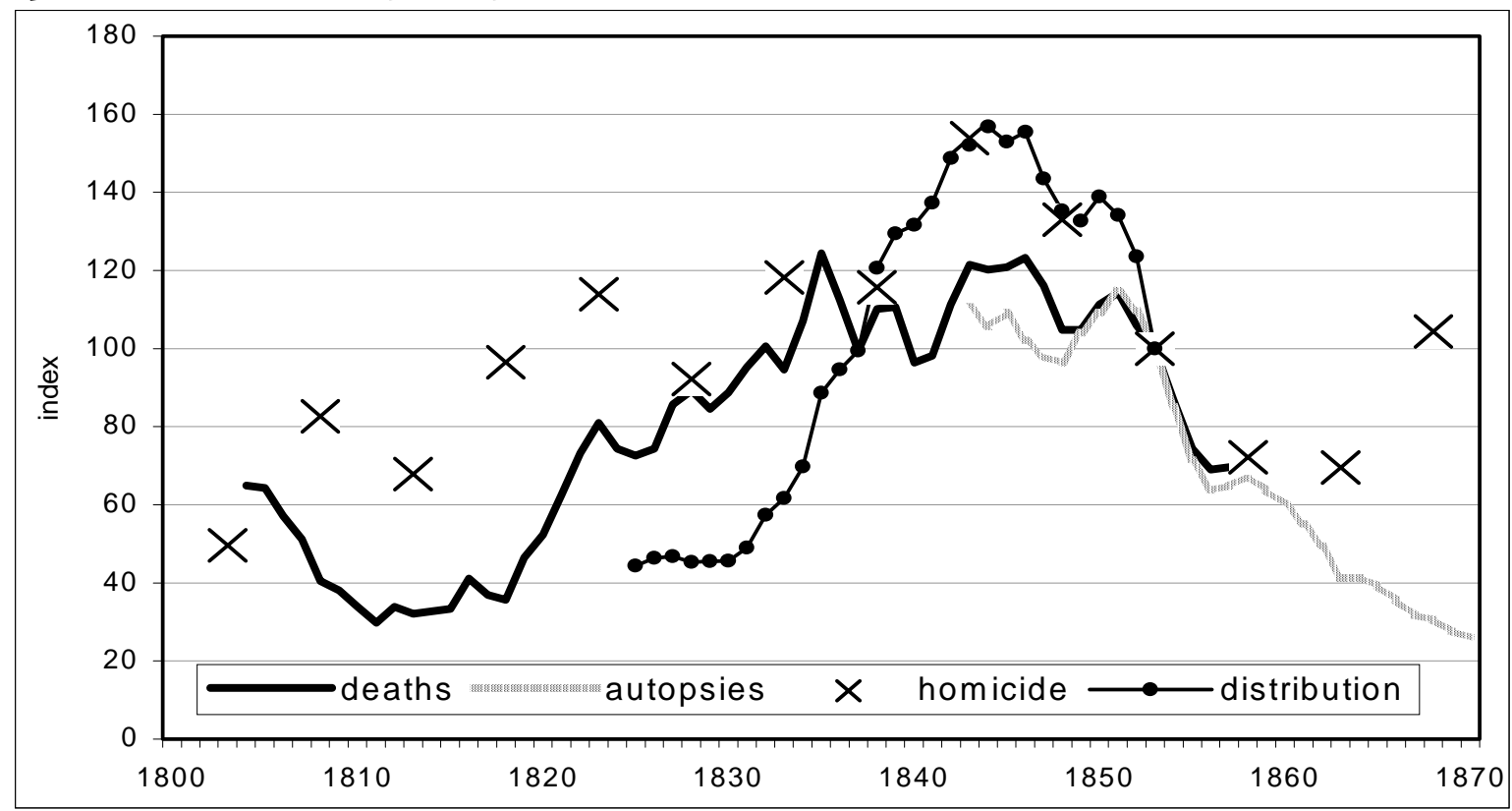

Sources: Sundhets-Collegii Underdåniga Berättelse om Medicinalverket $i$ Riket 1851 (deaths, autopsies 1802-51), Bidrag till Sveriges Officiella Statistik A, Befolkningsstatistik, 1851-60 (deaths 1852-60), Bidrag till Sveriges Officiella Statistik K, Helso- och sjukvården, 1852-70 (autopsies 185270). P. A. Siljeström, 'Om mord och sjelfmord i Sverige under tidskiftet 1750-1870', Statistisk Tidskrift, 1875 (homicide).

Comments: Deaths and autopsies concern acute alcohol intoxication. Data on homicide is based on official statistics on causes of deaths. The distribution series concerns the quantity of brännvin shipped out from ports of the county of Malmöhus to other parts of Sweden. All series are deflated by annual national population.

conflict and disorderly conduct observed in some local communities during the early nineteenth-century may also to some extent be attributed to more excessive drinking than before, although this phenomenon primarily appears to have been a consequence of social tension and tightening up of formal social control. ${ }^{40}$

Although there are no reliable statistics on consumption levels during this period, some data series can be used as indicators of the major trends (Figure 2). The reason for including homicide among the indicators is the empirical evidence of a positive correlation between alcohol consumption and the homicide rate in early nineteenth- as well as in twentieth-century Sweden. ${ }^{41}$

On the basis of evidence from these statistical series and to some extent from contemporary estimaties of alcohol consumption, in combination with narrative

1999), 188.

40 J. Sundin, För Gud, Staten och Folket (Lund, 1992), 295.

41 See, for example, H. v Hofer, Brott och straffi Sverige. Historisk kriminalstatistik 1750 1984. Diagram, tabeller och kommentarer (Stockholm, 1985); L. L. Lenke, Alcohol and Criminal Violence; Time series analyses in a comparative perspective (Stockholm, 1989). 
sources, such as the reports of the county governors, it is plausible to make some claims. Per capita consumption probably increased substantially during the early nineteenth-century and culminated around the middle of the 1840s, while an abrupt fall occurred in the middle of the 1850s subsequent to the new legislation on alcohol trade and production.

\section{Alcohol-Related Mortality}

We find few cases of explicit alcohol-related mortality in the official statistics from this period. According to the registration of deaths caused by acute alcohol intoxication, there were less than 50 cases per year on average during the first half of the nineteenth-century. ${ }^{42}$ Certainly, the mortality impact of alcohol consumption was much larger. In addition to direct physiological effects, heavy drinking may influence health-related behaviour and living conditions, for instance diet and housing, and can thus lead to increased risks of fatal accidents and susceptibility to infections.

The problems connected with the use of historical data on causes of death are well-known, for example due to changes in the official nomenclature and the vagueness and inaccuracy of many diagnoses. Thus the following conclusions should be regarded as highly tentative. ${ }^{43}$

Diagnoses like lung consumption (a proxy for lung tuberculosis), stroke and external causes (primarily accidents and suicides) made a large contribution to the disadvantageous development of male mortality on both the local and national levels (Table 1). According to modern medicine as well as to the opinion of nineteenth-century physicians, all these causes of death may be related to physiological or behavioural effects of excessive alcohol consumption, ${ }^{44}$ but certainly also to several other background factors.

42 Bidrag till Sveriges Officiella Statistisk. Tabell-kommissionens underdåniga berättelse för åren 1851 med 1855. Första afdelningen (Stockholm, 1857).

43 It should also be noted that the national figures only refer to a few years: 1776-1780 and $1826-1830$.

44 According to modern medicine excessive alcohol use is related to physical disabilities and premature death in several ways, for instance by increased risks of brain and liver damage, gastro-intestinal problems, hypertension, stroke and violent deaths (such as suicide, homicide, falling and drowning accidents). See, for example, C. S. Lieber, Medical Disorders of Alcoholism. Pathogenesis and Treatment (Philadelphia, 1982); Alcohol: Our Favourite Drug. New Report on Alcohol and Alcohol-Related Problems from a Special Committee of the Royal College of Psychiatrists (London, 1986). Physicians of the nineteenth-century claimed that mortality in stroke, pneumonia and violent deaths was affected by excessive drinking. See, for example, G. Westfelt, 'Om dryckenskapens tillstånd och fysiska följder i Sverige under åren 1861-77 enligt statistikens vittnesbörd. Föredrag vid nedläggandet af Ordförandeskapet i Svenska Läkare-Sällskapet d. 7 oktober 1879', Svenska Läkare-Sällskapet Nya Handlingar, Ser. II, del VII. 2 (Stockholm, 1880), 87. 
Table 1. Sex specific mortality rates and excess male mortality for different causes of death in ages 25-49. Linköping area (1780-1849) and Sweden (1776-1780/18261830). Per 10,000.

\begin{tabular}{lrrrrrr}
\hline \multicolumn{1}{c}{ Linköping Area } & \multicolumn{3}{c}{$1780-1814$} & \multicolumn{3}{c}{$1815-1849$} \\
& male & female & difference & male & female & difference \\
\hline Lung consumption & 28 & 25 & 3.1 & 39 & 28 & 10.8 \\
Other infections & 82 & 67 & 14.9 & 57 & 42 & 14.8 \\
Stroke/sudden death & 9 & 6 & 3.0 & 18 & 10 & 7.3 \\
Maternal mortality & - & 19 & -18.5 & - & 11 & -11.0 \\
External causes & 7 & 1 & 6.0 & 12 & 2 & 9.7 \\
Other causes & 26 & 26 & 0.4 & 24 & 23 & 0.3 \\
All causes & 152 & 143 & 9.0 & 149 & 117 & 32.1 \\
n & 1474 & 1576 & & 1426 & 1323 & \\
\hline \multicolumn{1}{c}{ Sweden } & \multicolumn{7}{c}{$1776-1780$} & & & & \\
& male & female & difference & male & female & difference \\
\hline Lung consumption & 22 & 18 & 4.6 & 37 & 27 & 9.8 \\
Other infections & 22 & 44 & 10.5 & 59 & 42 & 18.3 \\
Stroke/sudden death & 5 & 4 & 1.1 & 13 & 6 & 6.7 \\
Maternal mortality & - & 16 & -16.1 & - & 12 & -11.6 \\
External causes & 8 & 2 & 6.0 & 18 & 2 & 15.6 \\
Other causes & 28 & 26 & 1.7 & 33 & 26 & 5.9 \\
All causes & 118 & 110 & 7.8 & 160 & 115 & 44.7 \\
n & 19023 & 19556 & & 35004 & 27417 & \\
\hline
\end{tabular}

Sources: The Historical Database of Linköping and Befolkningsstatistiska tabeller from parish archives (Linköping area). Stiftstabeller and Rikstabeller from the archives of the Table Commission (Sweden).

Comments: The Linköping area consists of the town of Linköping and fourteen surrounding rural parishes. Lung consumption = lungsot (consumption of lungs) and tvinsot (wasting-away disease). Other infections $=$ primarily 'fevers' such as bröstfeber (breast-), hetsig feber (fever fits), nervfeber (nerve-), etc. Stroke $=$ slaglbrad död. The descriptions of symptoms of stroke from medical handbooks of the time largely resemble modern ones. The diagnosis probably includes diseases such as cerebral hemorrhage and heart infarct for adults. Maternal mortality = barnsbörd.

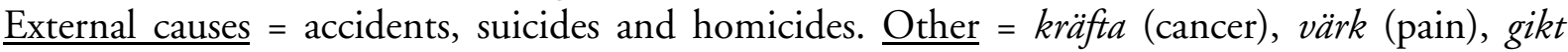
(gout), venerisk sjukdom (veneral disease), vattusot (dropsy), etc.

For further information, see S. Willner, Det svaga könet? Kön och vuxendödlighet i 1800-talets Sverige, Linköping, 1999.

Considering the hazards connected to working conditions, the considerable rise in the incidence of fatal accidents among men may to some extent have been an effect of the agrarian revolution and large public projects such as the construction of canals. As a consequence of land reclamation and enclosure reforms, certain types of work were intensified, such as clearing the land of stones and trees, digging 
ditches, etc. There was probably also an increase in transportation works connected to the expanding market for agricultural products. ${ }^{45}$

In reproductive ages deaths caused by pregnancies and deliveries certainly affected sex differential mortality. Declining maternal mortality contributed substantially to the widening of sex differences in mortality in the early nineteenthcentury, but it explains neither the growth of excess male mortality in several infectious diagnoses or external causes, nor the increased sex differential in prereproductive ages. ${ }^{46}$

It has been suggested that the heavy male excess mortality in early nineteenthcentury Stockholm was affected by the local labour market that favoured young women (working as maid-servants), while the male labour market was characterised by causal jobs and frequent unemployment. This interpretation is further supported by the fact that the poverty ratio (the proportion exempted from taxes) was higher among men than women in active ages. ${ }^{47}$ The poverty ratios in the Swedish countryside and the town of Linköping, however, point towards a more difficult economic situation for women than for men. ${ }^{48}$ And as women were socioeconomically disadvantaged, for example, by lower wages and restrictions that prevented women from engaging in most occupations, it does not seem likely that the excess male mortality in general was caused by economic conditions that discriminated against men. But it is probable that excessive drinking could affect health-related living conditions with regard to nutritional situation, housing conditions, etc.

45 C-J. Gadd, Järn och potatis. Jordbruk, teknik och social omvandling i Skaraborgs län 1750-1860 (Göteborg, 1983), Chapter VI.

46 S. Willner, Det svaga könet? Kön och vuxendödlighet i 1800-talets Sverige (Linköping, 1999), 47. See also, Ulf Högberg, Maternal Mortality in Sweden (Umeå, 1985).

47 J. Söderberg, et al., A Stagnating Metropolis: The Economy and Demography of Stockholm, 1750-1850 (Cambridge, 1991), 157.

48 S. Willner, Det svaga könet? Kön och vuxendödlighet i 1800-talets Sverige (Linköping, 1999), 72-74. 


\section{Alcohol Consumption and Mortality during the Industrial Breakthrough, c. 1860-1930}

\section{Alcohol consumption}

Figure 3. Per capita consumption of alcohol (ages 15+) in litres per year. Sweden $1861-1930$.

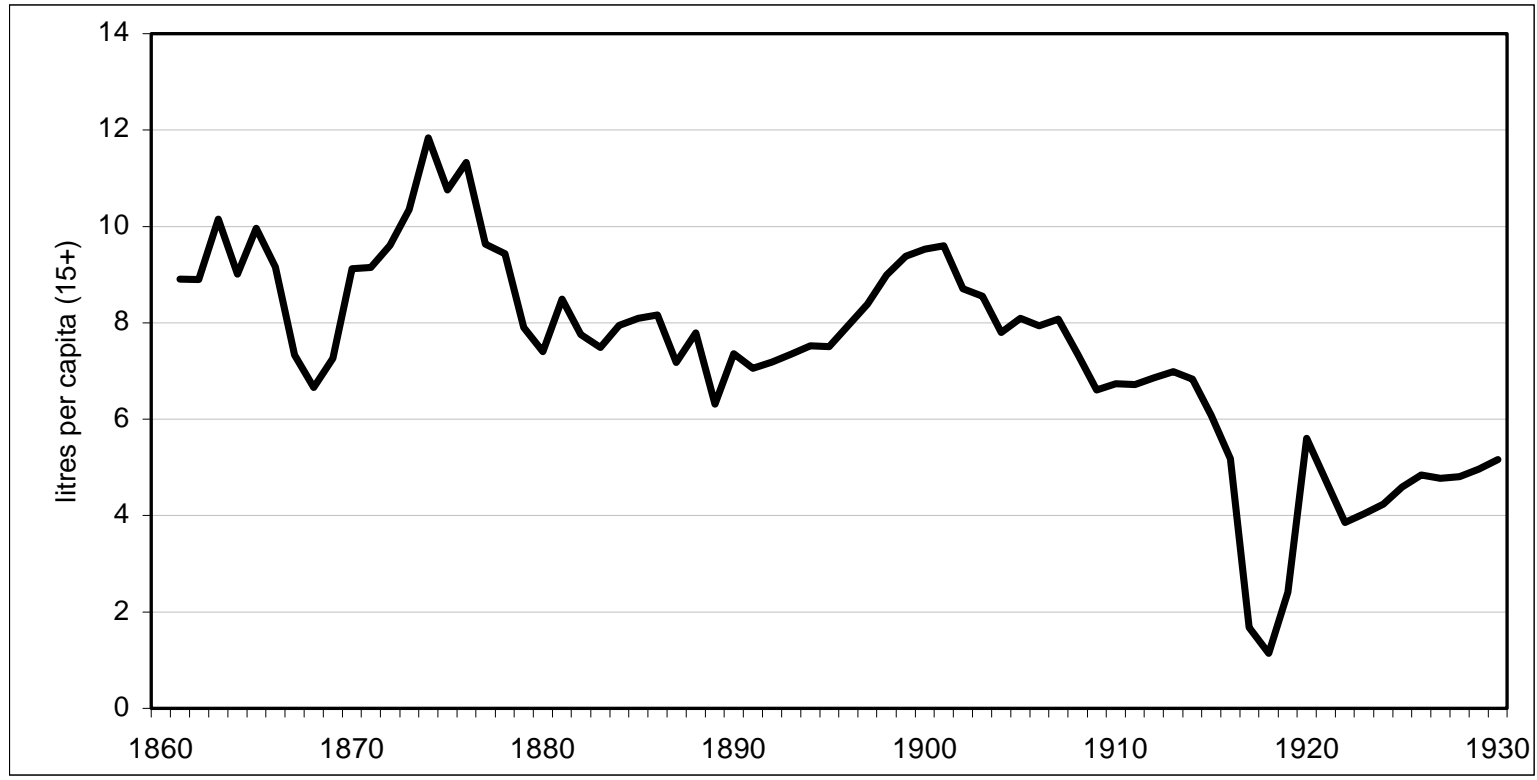

Sources: Bidrag till Sveriges Officiella Statistik V, Bränvins tillverkning och försäljning (18611869). L. Lenke, Alcohol, and Criminal Violence; Time Series Analyses in a Comparative Perspective, Stockholm, 1989 (1870-1930).

From the 1860s onward more reliable data are available on total alcohol consumption. Per capita consumption (ages 15+) fell in the long term from about nine litres per year in the early 1860 s to four to five litres in the 1920 s (Figure 3 ). A temporary drop in the late 1860s was connected to crop failures and declining real wages, while the peaks in mid-1870s and around the turn of the century coincided with economically more prosperous years. Modern time series analyses have confirmed that consumption level was positively related to changes in real wages in the late nineteenth-century. ${ }^{49}$

The dramatic decline during the last years of the First World War is an effect of restrictions motivated by the wartime crisis. Administrative control measures based on individual purchase restrictions were introduced in a number of towns in the early twentieth-century. Between 1919 and 1955 a compulsory system with indi-

49 T. Norström, 'Real wages, alcohol consumption and mortality in Sweden, 1861-1913', European Journal of Population, 4 (1988), 183-196. 
vidual liquor rationing and control (Brattsystemet) caused a levelling off of the annual alcohol consumption to about four to five litres per capita (ages 15+).

Although there is a positive correlation between annual fluctuations of real wages and alcohol consumption, in the long run the trends were in opposition to one another: wages increased while consumption levels fell. The latter was partly a product of a successively more restrictive attitude towards unrestrained drinking among people in general. This can be related to the increased discipline and control induced by the demands of the modern factory system, but also to the burgeoning ideal of conscientiousness among the working class, ${ }^{50}$ which also found expression in the expansion of the temperance movement during the late nineteenth-century. ${ }^{51}$ Although the referendum did not pass, the fact that almost one half of the Swedish voters (and nearly 60 per cent of the female voters) voted in favour of prohibition of alcohol in 1922 illustrates the great attraction of temperance ideals.

Several factors point to a considerable reduction in alcohol consumption in the countryside subsequent to the new alcohol legislation in mid-1850s. A large proportion of the rural inhabitants of Sweden came to live in dry areas. It was probably only towards the last decades of the century that a more significant reduction got underway in urban settings. One important factor was an increasing praxis from local governments to assign licenses to particular non-profit companies for the sale of spirits with the requirement that they operate in the public interest. This system became compulsory in 1905 .

\section{Alcohol-related mortality during late nineteenth-century}

During this period terms such as chronic alcoholism and delirium tremens, that reflected the long term effects of excessive drinking, were introduced and recorded in the official nomenclature of causes of deaths for Swedish towns. These deaths followed the fluctuations of per capita consumption on the national level relatively well until the late 1880 s, and to some extent, so did the sex ratio of mortality (Figure 4). ${ }^{52}$ However, the increasing consumption in the last decade of the century did not affect the mortality levels, according to the same data. This may have been a result of more restrictive policies and attitudes towards excessive alcohol consumption in the towns, and also because of changes in drinking patterns. The share

50 See, for example, B. Horgby, Den disciplinerade arbetaren (Stockholm, 1986); R. Ambjörnsson, Den skötsamme arbetaren (Stockholm, 1988).

51 J. Bergman, Den svenska nykterhetsrörelsens historia (Stockholm, 1913), 174.

52 Unfortunately there are no reliable data on causes of death outside the administrative towns during this period. 
Figure 4. Indices of alcohol consumption, alcohol-related deaths and sex ratio of mortality rates among adults in Swedish towns. 1880=100.

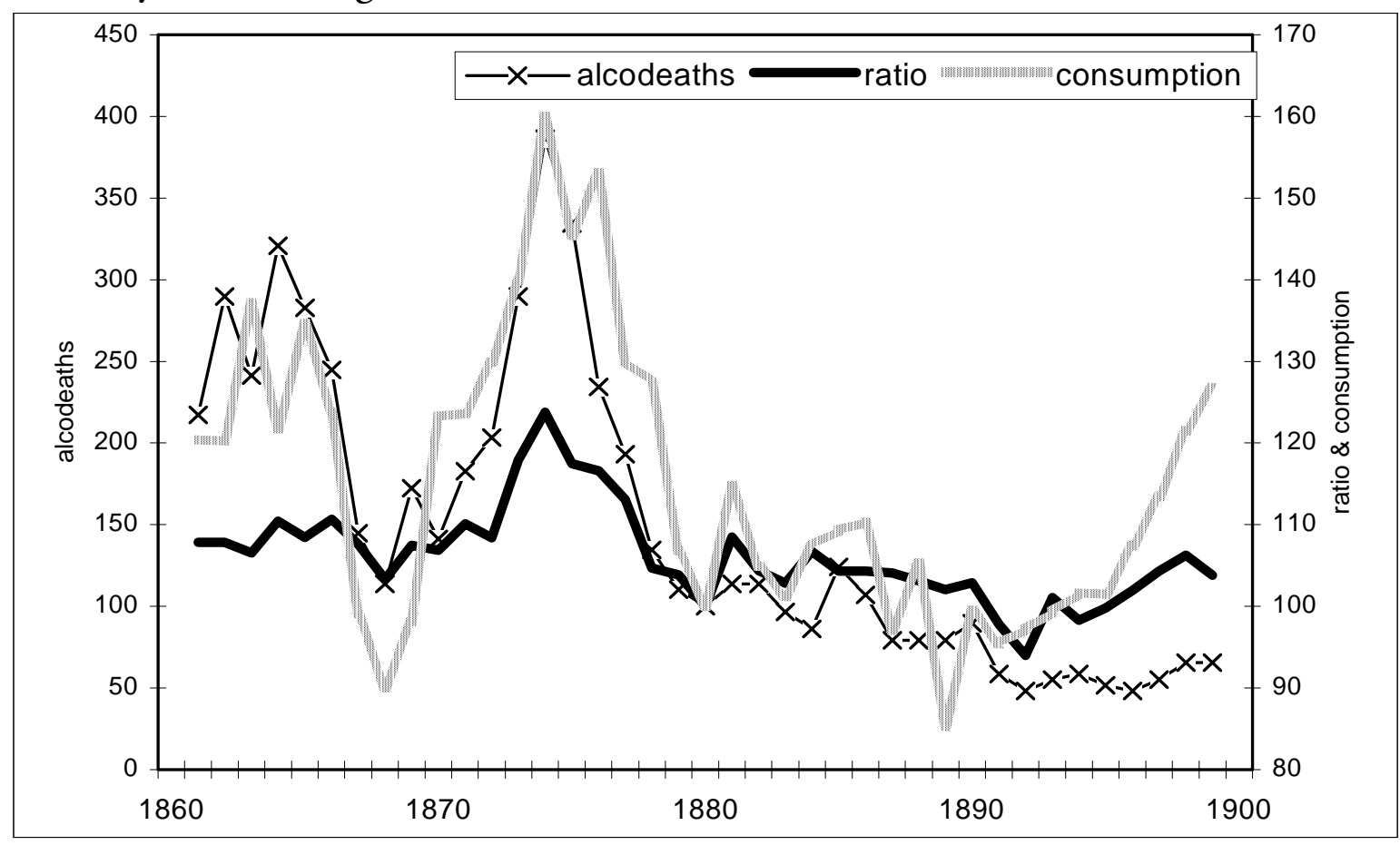

Sources: Alcohol consumption: see Figure 3. Alcohol-related deaths: BiSOS A, Befolkningsstatistik (1861-1863), BiSOS K, Helso- och sjukvairden (1864-1870/1875-1899), G. Westfelt (1880) (18711874). Sex ratio of mortality: BiSOS A.

Comments: Alcohol consumption =litres $100 \%$ alcohol per capita (15+) on national level. Alcohol-related deaths =death rates in 'chronic alcoholism' and 'delirium tremens' among men (15+) in towns. Sex ratio of mortality =urban population $(20+)$; females $=100$.

of stronger alcoholic beverages decreased, while beer drinking became clearly more popular during the last decades of the century. ${ }^{53}$

The simultaneous peaks of alcohol consumption, alcohol-related deaths and the sex ratio of mortality in the mid-1870s clearly indicated the importance of alcohol consumption for excess male mortality, according to contemporary observers like Gerhard Westfelt. Certainly, intensified drinking, stimulated by the economic upswing, contributed to this pattern, but we also know that times of industrial prosperity during the early phases of industrialisation led to increased migration into urban areas, causing growing problems of overcrowding, bad sanitation and transmission of infectious diseases. A majority of the migrants during the industrial booms were men. At least in Stockholm, a large part of those living in overcrowded and extremely unsanitary habitations, such as lodging houses and hostels, were single males. ${ }^{54}$ These miserable living conditions certainly constituted a hotbed for

53 S. Willner, Det svaga könet? Kön och vuxendödlighet i 1800-talets Sverige (Linköping, 1999), 191.

54 See, for example, K. A. Tengdahl, Material till bedömande af hamnarbetarnes i Stockholm lefnadsförhållanden (Stockholm, 1897). 
Table 2. Excess male mortality in ages 40-59 in Swedish towns $1875 / 79$ and 1895/99. Per 10,000.

\begin{tabular}{lrrrrrr}
\hline & \multicolumn{3}{c}{$1875-1879$} & \multicolumn{3}{c}{$1895-1899$} \\
\cline { 2 - 7 } & male & female & difference & male & female & difference \\
\hline Lung tuberculosis & 67 & 36 & 31.2 & 38 & 24 & 14.2 \\
Other infections & 11 & 7 & 4.7 & 2 & 1 & 0.3 \\
Respiratory diseases & 51 & 21 & 30.2 & 27 & 12 & 14.8 \\
Cancer & 15 & 19 & -3.4 & 17 & 17 & 0.1 \\
Diseases of the circulatory system & 15 & 9 & 6.4 & 21 & 14 & 7.0 \\
Diseases of the brain and the & 26 & 10 & 16.0 & 14 & 7 & 7.1 \\
$\quad$ nerve system & 17 & 12 & 5.0 & 9 & 6 & 3.3 \\
Diseases of the digestive system & 16 & 10 & 6.1 & 11 & 6 & 4.5 \\
Diseases of the genito-urinary & & & & & & \\
$\quad$ system & 9 & 0 & 8.7 & 3 & 0 & 2.7 \\
Alcoholism & 11 & 1 & 9.3 & 9 & 1 & 7.8 \\
Accidents & 6 & 1 & 5.2 & 7 & 1 & 6.4 \\
Suicide & 11 & 7 & 4.7 & 12 & 8 & 4.1 \\
Other causes & 17 & 9 & 8.0 & 17 & 5 & 11.3 \\
Unknown & 273 & 141 & 132.1 & 185 & 102 & 83.6 \\
All causes & 7766 & 5514 & & 8126 & 5940 & \\
n & & & & & & \\
\hline
\end{tabular}

Sources: BiSOS K, Helso- och sjukvården. Sundhets-collegii underdåniga berättelse 1875-79, 1895-99.

the spread of infectious diseases, such as the 1870s typhus epidemics in Stockholm, which struck adult males in particular. ${ }^{55}$ Such quarters probably also promoted excessive drinking habits.

In late nineteenth-century, the explicit alcohol-related diagnoses (chronic alcoholism and delirium tremens) only amounted to a small percentage of total male mortality in urban Sweden (Table 2). The decline from 9 deaths/10,000 in 1875-79 to $3 / 10,000$ twenty years later in ages $40-59$, however, indicates a substantial reduction of the unfavourable effects of alcohol on male health. The relatively more advantageous development of mortality for males than females in causes of deaths such as lung tuberculosis and brain diseases (including stroke or cerebral haemorrhage) could also to some extent be attributed to more moderate drinking habits. The decline in fatal accidents, in spite of increasing work hazards connected to the industrialisation process, may have been an effect of the same development.

55 K. Linroth, Dödsorsakerna och dödligheten i Stockholm 1871-1890 (Stockholm, 1892), 26. 


\section{Alcohol-Related Mortality during Early Twentieth-Century}

Figure 5. Alcohol consumption per capita (ages 15+) and sex ratio of mortality (females=100) for ages 40-59 in Sweden 1890-1930.

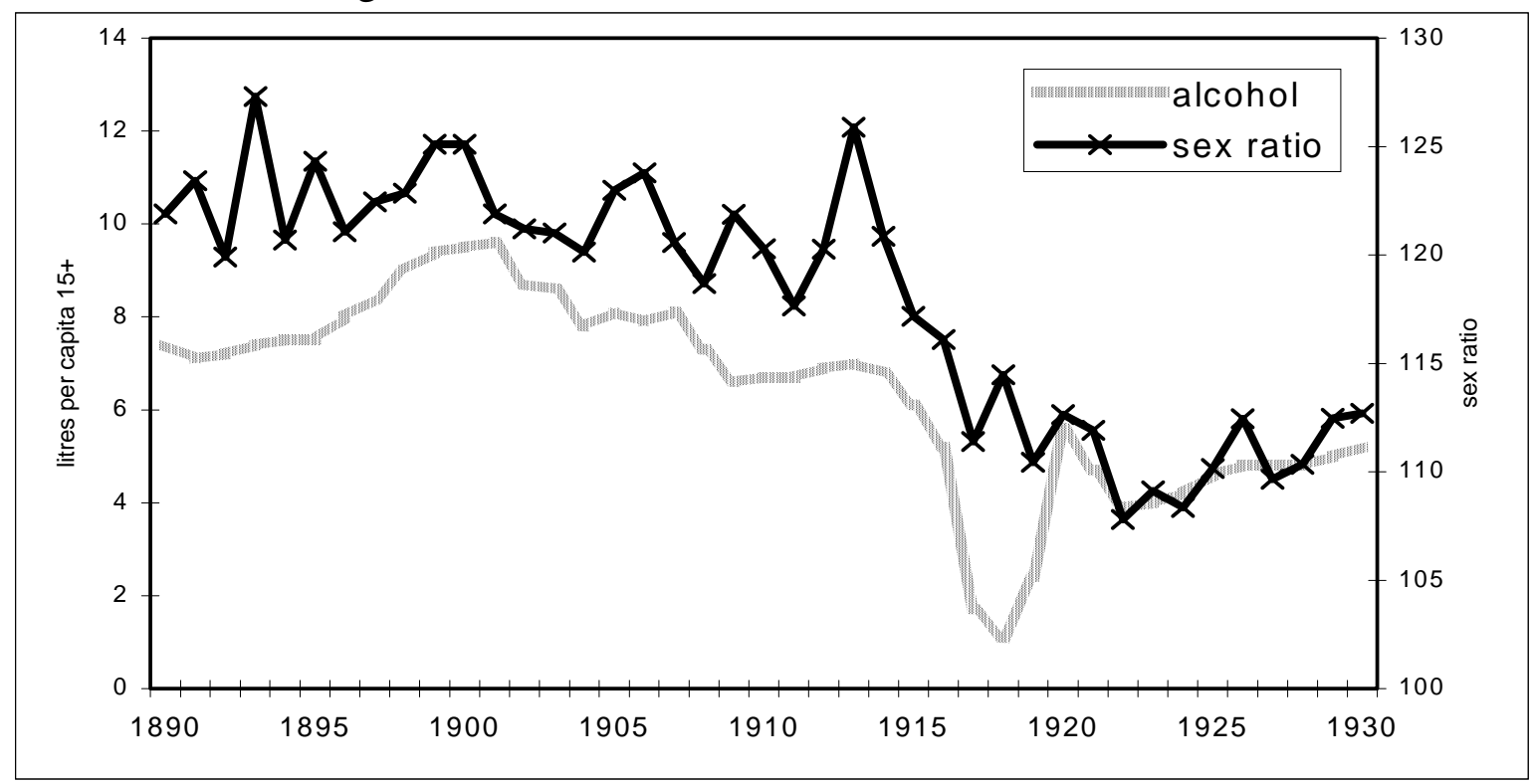

Sources: Alcohol consumption; see Figure 3. Sex ratio of mortality: BiSOS A and SOS. Befolkningsrörelsen.

Figure 6. National alcohol consumption per capita (ages 15+) and sex ratio of mortality (females=100) for ages 25-65 in Copenhagen, Denmark, 1895-1925.

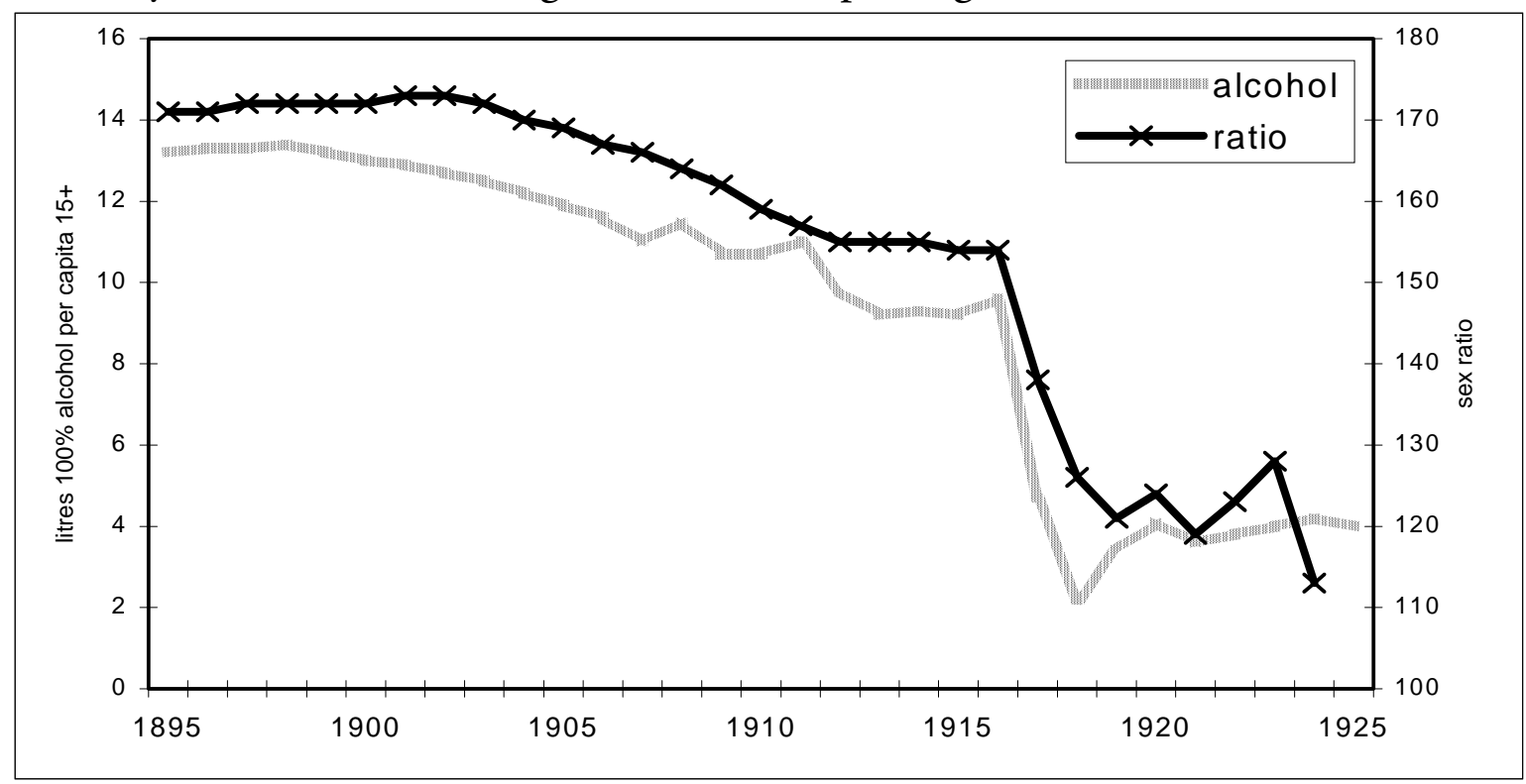

Sources: Alcohol consumption; T. Thorsen, Hundrede års alkoholmisbrug (Copenhagen, 1990), Tables 3.1 and 7.1. Sex ratio of mortality; Betænkning afgiven of den af indenrigesministeriet under 16. Juli 1914 nedsatte 2. Æedruelighedskommission, II afsnit, (Copenhagen, 1927), 707. Comments: Interpolated figures for alcohol consumption 1895-1905 and sex ratio 1895-1916. Other years annual data. 
Table 3. Sex specific death rates and excess male mortality in ages 40-59 in Sweden $1911 / 20$ and 1921/30. Per 10,000.

\begin{tabular}{|c|c|c|c|c|c|c|c|c|c|}
\hline & \multicolumn{3}{|c|}{ 1911-1916 } & \multicolumn{3}{|c|}{$1917-1920$} & \multicolumn{3}{|c|}{ 1921-1930 } \\
\hline & male & female & difference & male & female & difference & male & female & difference \\
\hline Tuberculosis & 20 & 20 & 0.1 & 17 & 17 & -0.3 & 13 & 13 & 0.5 \\
\hline Influenza & 0 & 0 & 0.1 & 12 & 11 & 1.2 & 1 & 1 & 0 \\
\hline Other infections & 3 & 2 & 1.2 & 4 & 2 & 1.3 & 4 & 3 & 0.8 \\
\hline $\begin{array}{l}\text { Respiratory dis- } \\
\quad \text { eases }\end{array}$ & 14 & 9 & 4.3 & 13 & 9 & 3.7 & 9 & 7 & 2.3 \\
\hline Cancer & 17 & 19 & -1.1 & 16 & 19 & -3.0 & 16 & 19 & -3.2 \\
\hline $\begin{array}{l}\text { Diseases of the } \\
\text { circulatory sys- } \\
\text { tem }\end{array}$ & 13 & 13 & 0.4 & 12 & 13 & -0.7 & 13 & 13 & 0.1 \\
\hline $\begin{array}{l}\text { Diseases of the } \\
\text { brain and } \\
\text { nervous system }\end{array}$ & 8 & 7 & 1.1 & 7 & 6 & 0.5 & 6 & 6 & 0.0 \\
\hline $\begin{array}{l}\text { Diseases of the } \\
\text { digestive sys- } \\
\text { tem }\end{array}$ & 7 & 6 & 0.8 & 7 & 6 & 1.3 & 7 & 6 & 0.8 \\
\hline $\begin{array}{l}\text { Diseases of the } \\
\text { genito-urinary } \\
\text { system }\end{array}$ & 6 & 5 & 0.9 & 6 & 5 & 0.9 & 5 & 5 & 0.3 \\
\hline Alcoholism & 1 & 0 & 0.8 & 0 & 0 & 0.2 & 0 & 0 & 0.2 \\
\hline Accidents & 7 & 1 & 6.4 & 6 & 1 & 5.2 & 5 & 1 & 4.4 \\
\hline Suicide & 6 & 1 & 4.4 & 4 & 1 & 2.7 & 5 & 1 & 3.9 \\
\hline Unknown causes & 3 & 4 & -0.2 & 3 & 3 & -0.1 & 2 & 2 & 0.2 \\
\hline Other causes & 5 & 6 & -1.2 & 5 & 5 & -0.7 & 4 & 6 & -1.5 \\
\hline All causes & 111 & 93 & 18.1 & 111 & 99 & 12.1 & 91 & 82 & 8.6 \\
\hline number & 33522 & 31472 & & 23710 & 23268 & & 53240 & 51949 & \\
\hline
\end{tabular}

Sources: SOS. Dödsorsaker.

The dramatic decline in alcohol consumption during the First World War was followed by an instant fall in excess male mortality levels in Sweden as well as in the Danish capital (Figures 5 and 6). A clear reduction of mortality in causes of death such as alcoholism, liver cirrhosis, pneumonia, kidney diseases, stroke and external causes was observed among adult males (25-65 years) in Copenhagen, while mortality levels for those diagnoses remained more or less unchanged among females. ${ }^{56}$

A more advantageous development of similar diagnoses among males than among females can also be observed in Sweden (Table 3). Cerebral haemorrhage (in the category diseases of the brain and nerve system) was reduced by about 25 per cent among males, but by less than 10 per cent among females when 'the low consumption period', 1921-1930, as compared to the 'high consumption period', 19111916. Chronic inflammation of the liver (in the group diseases of the digestive system)

56 Those diagnoses were reduced by 50\% among men (25-65 years of age) but only by $15 \%$ among women in the period 1918/22 compared to 1910/14, according to an official Danish report in 1927: Betenkning afgiven af den af indenrigesministeriet under 16. Juli 1914 nedsatte 2. Eedruelighedskommission, II afsnit (Copenhagen, 1927), 712. 
declined by 40 per cent for males and by 10 per cent for females, while fatal accidents fell by 30 per cent among men and less than 15 per cent among women. The diagnosis alcoholism dropped by 80 per cent among men, while the female death rate was insignificant during both periods: less than one case per 100,000. In the case of the dominating infectious cause of death, tuberculosis, however, the relative decline was similar for both sexes, c. 35 per cent. These effects are to some extent visible even in the intermediate period, 1917-20, when consumption figures reached the lowest level. The picture is, however, somewhat complicated because of the extraordinary impact on death rates caused by the Great Influenza Epidemic, 1918-19. The epidemic particularly struck young males, thus counteracting effects of the fall in alcohol consumption and resulting in a pronounced peak of the sex ratio of mortality (Figure 1).

To conclude, it is certainly difficult to separate the effect of alcohol from other potential background factors when discussing most causes of death, but, on the other hand, it is hard to find any other factor that so convincingly explains the clear decline of the sex differential ratio during the First World War, observed both in Sweden and Denmark, than the simultaneous fall in per capita alcohol consumption.

If we extend the period of examination beyond the inter-war period and the Second World War, we find a clear upswing of alcohol consumption in 1956, the first year following the abolition of the individual ration system (Brattsystemet, 19191955). As a result, a policy of high taxes on alcoholic beverages was introduced in order to reduce demand. However, the subsequent development was characterised by a successive upward trend in per capita consumption (ages 15+) from approximately five litres in early 1950s to about eight litres in mid-1970s, according to official statistics. Previous studies suggest that the increased use of alcohol and tobacco during the post-war period, associated with rising welfare and real wages, has been important for the simultaneous increase in excess male mortality. ${ }^{57}$

57 Ö. Hemström, 'Explaining Differential Rates of Mortality Decline for Swedish Men and Women: A Time-Series Analysis, 1945-1992', Social Science and Medicine, 48:12 (1999), $1795-1777$. 


\section{Differences in the Effect of Alcohol among Different Categories of Men}

\section{Urban-rural and marital status differences}

Urban environments generally produced higher mortality levels than rural ones. This was especially marked among single men, while the urban-rural differential as well as marital status differences in mortality were much smaller among females. This general 'urban penalty' for men as well as the extremely high death rates of bachelors are attributed to excessive drinking by contemporary observers. ${ }^{58}$

Some local Swedish mortality data for the late nineteenth-century, specified for marital status and causes of death, indicate higher levels of alcohol-related deaths for unmarried men than for those married..$^{59}$ A statistical investigation from the Norwegian capital at the turn of the century $1900,{ }^{60}$ as well as Swedish data on persons arrested for the offence of drunkenness, provide further evidence supporting the idea of higher consumption levels among single men. Unmarried men were clearly over-represented among those arrested for drunkenness. According to official statistics, the rate of arrested bachelors was more than five times higher than that of married men in ages over 40 in 1917, which clearly indicates that heavy drinking was more common among single men. ${ }^{61}$ Whether this was primarily a result of selective mechanisms on the marriage market or protective effects of marriage remains an open question. Probably it was a combination of both factors.

The development of death rates, specified for marital status and urban-rural living, support the idea that the mortality response to variations in alcohol consumption levels was strongest among urban bachelors (Figure 7). The peaking of the mortality-index in mid-1870s, as well as the increase in late nineteenth-century and the marked fall during the First World War, clearly follow the fluctuations in consumption previously described. But it is also likely that other factors contributed to

58 M. Huss, Alcoholismus chronicus eller Chronisk Alkoholsjukdom, II (Stockholm, 1851), 166-167; R. Tigerstedt, Spriten och människan (Stockholm, 1896).

59 Death rates for the town of Linköping 1861-1891: S. Willner, 'Gender and mortality in 19th century Sweden', paper presented at 13th Nordic Demographic Symposium in Umeå (1999).

60 A. N. Kiær, Statistiske undersogelser vedkommende adruelighedsforhold og forbrug af alkoholholdige drikke i Kristiania 1900 (Kristiania, 1909).

61 Calculated from data found in Sveriges Officiella Statistik; Undersökningar angående alkoholens sociala skadeverkningar (Kungl. Socialstyrelsen, 1921), and SOS, Befolkningsrörelsen 1917 (population figures). According to this report a majority (circa 56\%) of the arrested bachelors and a good third of the arrested (circa 36\%) of married men in age group 40-49 were alcoholics. 
Figure 7. Mortality specified for sex and marital status for ages 40-59. Index: married female $=100$. Death rates per 1,000 for married females. Moving 5-year averages.

a) Urban Sweden

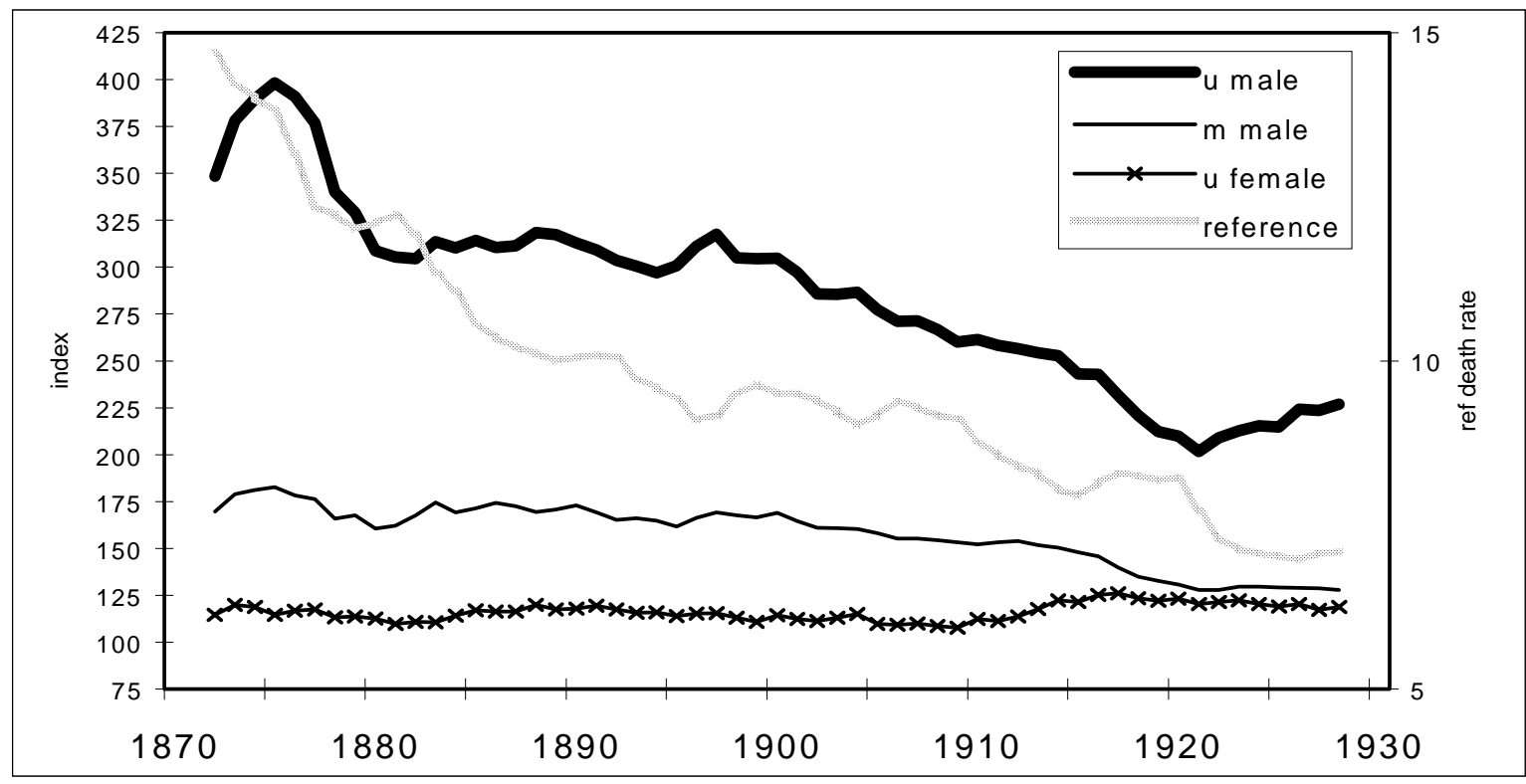

b) Rural Sweden

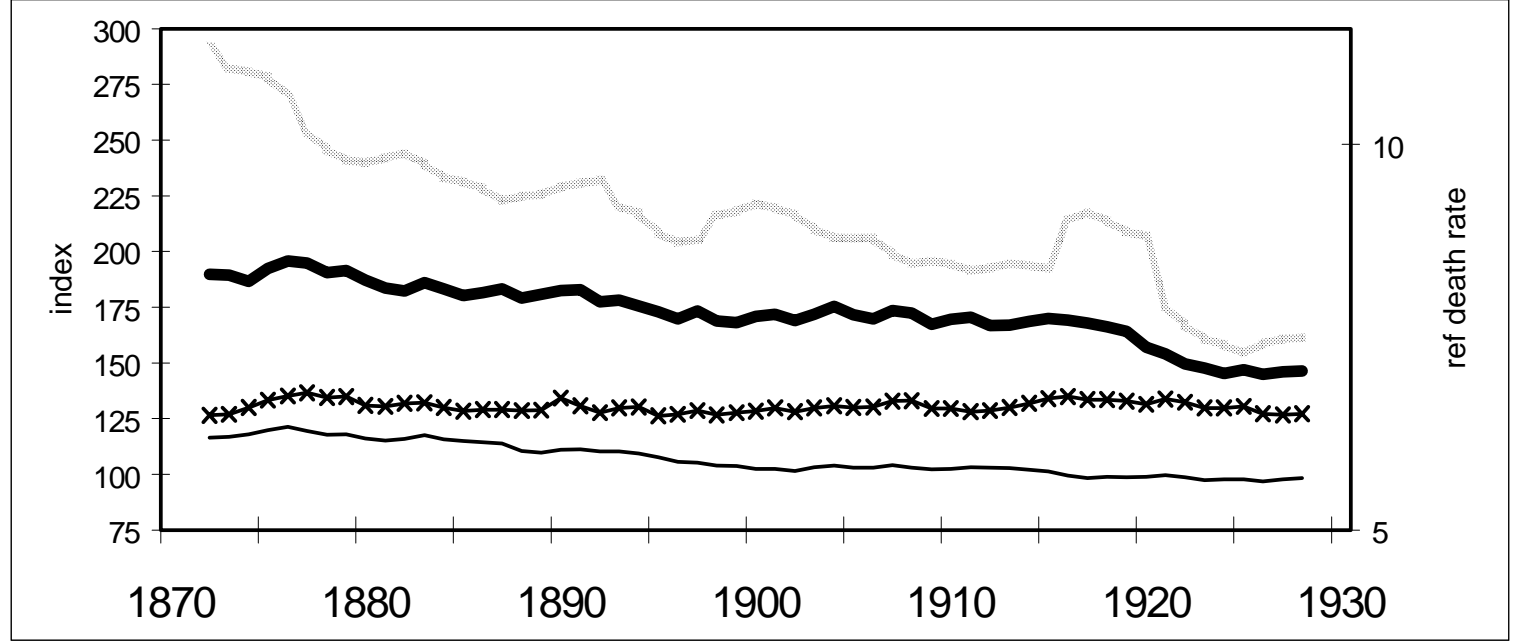

Sources: BiSOS A and SOS. Befolkningsrörelsen.

Commentaries: $\mathrm{u}=$ unmarried, $\mathrm{m}=$ married, reference $=$ married females.

this pattern. The worsening of health problems connected to increased migration, overcrowding and bad sanitation during economic upswings (for example in the 1870s and the 1890s) struck harder among unmarried men, who often lived under more miserable conditions than their married brothers. 


\section{Social Differences in Mortality}

Our knowledge of social differences in adult mortality in nineteenth-century Sweden is limited to a few local studies. During the pre-industrial or transitional period of the early nineteenth-century the 'expected' differences have been found for adult males both in the town of Linköping and in the rural surroundings of Sundsvall. The highest mortality was found among the workers and property-less and the lowest levels in higher social classes. There were no clear, or very small, differences among women. ${ }^{62}$ According to contemporary observers, excessive drinking was much more widespread among the lower social classes, and this may have been one background factor for the marked social differentials in mortality for men. It also seems reasonable to suggest that behavioural effects, e. g. an increased disposition for heavy drinking resulting from socio-economic stress in a transitional society, were more pronounced among the non-propertied classes. Probably differences in work hazards and socio-economic conditions also contributed to mortality differences among social classes as well as between men and women. However, a puzzling mystery is why clear social differences in mortality are not discernible among the female population, as particularly married men and women to a large extent shared the same living conditions. This rather supports the idea that factors primarily affecting male health, e. g. excessive drinking or certain work hazards, were of great importance for producing social differences in mortality, alternatively (or even in addition), that men were more susceptible to socio-economic stress effects.

In contrast to the results from the early nineteenth-century, evidence from the towns of Sundsvall and Linköping during the later part of the nineteenth-century rather points to higher alcohol-related death rates among middle class men than male among workers, with no significant social differential in total mortality. ${ }^{63}$ The absence of clear differences between social classes does not, however, eliminate the possibility of differences between specific occupational groups. It is well known from the literature that collective drinking was highly integrated in certain groups of male workers, such as craftsmen, sailors and dockers. ${ }^{64}$ According to contempo-

62 Linköping 1805-1848: J. Sundin, 'Gender and Mortality in Sweden 1750-1900: Results from an Ongoing Project', in New Countries and Old Medicine eds. L. Bryder and A. Dow, (Auckland, 1995); Rural Sundsvall 1803-1859: S. Willner, 'Sex and class differentials in mortality in Sweden during the two last centuries', paper presented at the Social Science History Association Annual Meeting in Pittsburgh (2000).

63 Sundsvall: S. Edvinsson, Den osunda staden. Sociala skillnader $i$ dödlighet $i$ 1800-talets Sundsvall (Umeå, 1992); Linköping: S. Willner, Det svaga könet? Kön och vuxendödlighet i 1800talets Sverige (Linköping, 1999), 204.

64 L. Magnusson, Den bråkiga kulturen. Förläggare och smideshantverkare i Eskilstuna 1800-1850 (Stockholm, 1988); M. Huss, Alcoholismus Chronicus eller Chronisk Alkoholsjukdom, II (Stockholm, 1851), 172-173; K. A. Tengdahl, Material till bedömande af hamnarbetarnes $i$ 
rary data from Danish towns and the annual reports of the Registrar General in England, alcohol-related deaths, as well as total mortality, were clearly higher among working class men in general and for certain occupational groups in particular: for example, unqualified workers and occupations handling alcoholic beverages. ${ }^{65}$

In the light of this international evidence and with regard to the scarcity of Swedish data regarding social differentials in mortality, we have to be cautious with more definite conclusions. On the basis of our present knowledge, a reasonable conclusion is that clear social differences in mortality among adult males probably existed in early nineteenth Sweden, meaning higher death rates for lower social classes than for higher. Excessive drinking, presumably stimulated by socioeconomic stress among the proletarians, contributed to this pattern. During the industrial breakthrough in late nineteenth-century (compared to the pre-industrial period) there were relatively small or non-significant social differences in male mortality in general or in alcohol-related deaths. The growth of an ideal of conscientiousness and temperance among large groups of the working class, as well as the improved standard of living in the long term, are some factors that may explain the absence of pronounced social differences in male mortality in contrast to the preindustrial period.

\section{Conclusions}

The analyses corroborate the hypothesis of an alcohol boom during the period from 1820 to the 1840 s or early 1850 s. Results from previous studies suggest that annual fluctuations in per capita consumption of alcohol had a certain impact on adult male mortality in late nineteenth-century Sweden. According to evidence presented here, more substantial changes in aggregated alcohol consumption levels had a clear impact on the male/female mortality ratio in eighteenth and early nineteenthcentury Sweden (Figure 8). Increasing consumption led to more pronounced excess male mortality, while falling consumption coincided with a levelling out of sex differentials in death rates. This could be observed during the upswing and fall of the alcohol boom in early nineteenth-century and in conjunction with the reductions of consumption during the First World War.

Stockholm lefnadsförhållanden (Stockholm, 1897).

65 T. Sørensen, De økonomiske Forholds og Beskjaftigelsens Inflydelse paa Dødeligheden (Copenhagen, 1884-85). 
Figure 8. Sex specific mortality rates and ratio (females=100) for ages 40-59. Sweden 1790-1930. Ratio = moving five-year averages.

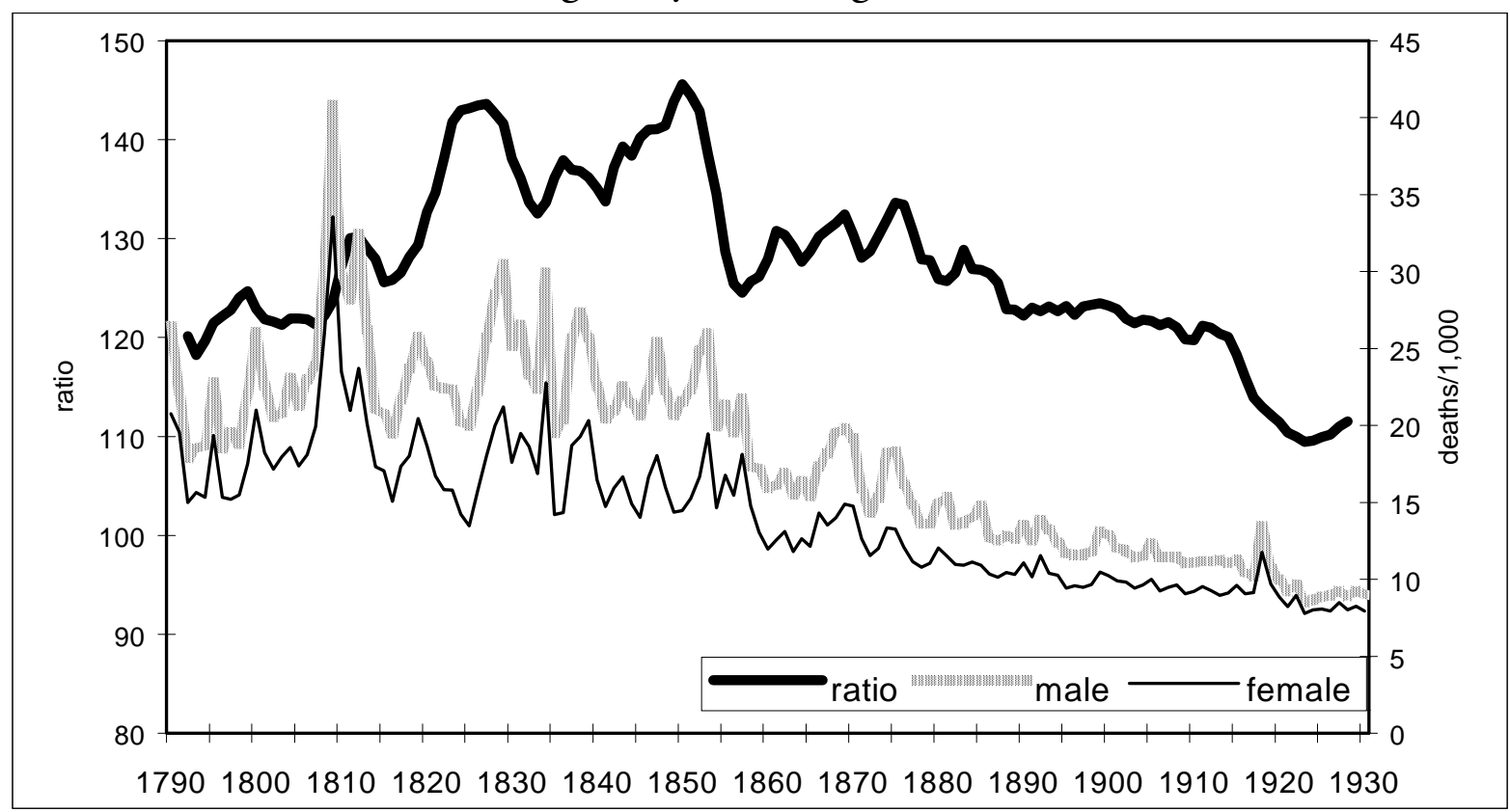

Sources: G. Sundbärg, 'Döde efter kön, ålder och civilstånd i Sverige åren 1751-1900 samt Medelfolkmängden efter kön och ålder under femårsperioderna för samma tid', Statistisk Tidskrift (1905); BiSOS A; SOS. Befolkningsrörelsen.

Some evidence from the late nineteenth-century was found supporting the hypothesis that alcohol consumption might also be a central factor in producing differential mortality between certain categories of men, with regard to marital status, social class or urban-rural residence. Men living in urban areas, where the great availability of licensed premises and urban life style factors probably promoted drinking, generally experienced clearly higher death rates than their rural brothers. Unmarried men, presumably on average more prone to drinking than their married counterparts, had substantially higher mortality than married men. In addition, the mortality response to variations in per capita alcohol consumption was particularly strong among urban bachelors. This result supports the idea that alcohol was an important factor in male mortality.

Evidence of social differences in mortality as well as in alcohol consumption is scarce. However, some indications have been found of the heavy drinking among the proletarian groups in the transitional society of early nineteenth-century which in all likelihood contributed to more disadvantageous death rates for working class men than for higher social classes. Improvements in the standard of living and the influence of temperance ideals during the industrial breakthrough may have helped diminish social differences in male mortality.

But what then caused alcohol consumption to increase or decline? The more substantial changes can obviously be attributed to radical administrative measures: the restrictions imposed on production and trade of liquor in 1855 and the intro- 
duction of a compulsory individual ration system (Brattsystemet) in 1919, preceded by local initiatives and temporary restrictions during the First World War. Concerns regarding the social and medical effects of excessive drinking motivated these legislative reforms, although certainly economic interests also played an important role for the reforms of the 1850s.

The more gradual changes or long term trends in consumption may have been affected by common conceptions and knowledge of the effects of alcohol consumption and general attitudes towards drinking, that to a large extent were influenced and limited by socio-economic conditions and legal regulations. For instance, did the importance of social drinking in certain male occupational cultures and common beliefs about the positive effects of alcohol for coping with hard work and poor living conditions promote high consumption levels in preindustrial society? The process of proletarianisation and socio-economic stress in the early nineteenth-century, in combination with improvements in liquor production, gave further stimulus to excessive drinking. A growing concern regarding the negative socio-economic and medical effects of excessive drinking, influenced by the propaganda of the new absolutist temperance movement and other branches of the expanding popular movements (the labour movement and the free churches) and the demands of industrial production, contributed to the development of sober and disciplined working class men.

According to previous studies, short-term variations in aggregate consumption levels were clearly correlated with economic fluctuations. Times of crop failures or falling real wages were followed by shrinking alcohol consumption, while prosperous years tended to increase the levels. In the long term, however, the trends during the industrial breakthrough were the opposite; wages increased, while consumption levels declined.

These results provide further strong support for the idea that alcohol consumption had a considerable impact on sex differences in mortality in nineteenth and early twentieth-century Sweden, particularly for middle-aged males. Thus, gender related life style factors appear to have played an important role for sex differentials in mortality in the transitional and industrial society of the past. This is also largely true in late twentieth-century Sweden, in spite of huge differences in socioeconomic and cultural conditions as well as in the major causes of death.

The interaction of socio-economic and cultural factors has to a large extent affected both short-term fluctuations and as more long-term trends of alcohol consumption in nineteenth and twentieth-century Sweden. The results of the analyses further suggest that administrative measures, whether by rationing or other regulations of availability or by fiscal policy, have been very effective in regulating consumption levels and consequently have affected excess male mortality.

\section{Sam Willner, Ph.D., Department of Health and Society, Linköping University}

